\title{
A RETROSPECTIVE HISTOPATHOLOGICAL STUDY OF 120 CASES OF CHOLECYSTECTOMY SPECIMENS IN BARABANKI DISTRICT OF UTTAR PRADESH
}

\author{
Sadaf Mirza1, Mohammad Kashif², Arshad Ikram³
}

${ }^{1}$ Assistant Professor, Department of Pathology, Mayo Institute of Medical Sciences, Barabanki, Uttar Pradesh, India.

${ }^{2}$ Assistant Professor, Department of Paediatrics, Mayo Institute of Medical Sciences, Barabanki, Uttar Pradesh, India.

${ }^{3}$ Professor, Department of Pathology, Mayo Institute of Medical Sciences, Barabanki, Uttar Pradesh, India.

\author{
ABSTRACT

\section{BACKGROUND} \\ Gallbladder is an important organ of the body, where the storage and concentration of bile takes place. More than $95 \%$ of the \\ biliary tract disease is attributed to cholelithiasis (gall stones). The gall bladder pathology ranges from cholecystitis to highly lethal \\ carcinoma. \\ The present study was conducted to review the significant histopathological findings encountered in gallbladder specimens \\ received in our institute.
}

\section{MATERIALS AND METHODS}

In this retrospective descriptive study, one hundred and twenty (120) cholecystectomy specimens were studied over a period of two years (January 2015 to December 2016). It was conducted in Department of Pathology, Mayo Institute of Medical Sciences, Barabanki, UP, India. The histopathological changes in the gallbladders were examined and correlation with age, sex and religion was evaluated.

\section{RESULTS}

A total of 120 cholecystectomy specimens were received over a period of 2 years. The mean age of the patients was 45 years (Age range 10 - 80 years) with Male: Female ratio of 1: 3.5. Histopathologically, the most common lesion was inflammation (91.7\%) followed by tumour-like lesions (6.0\%) and then carcinoma gallbladder $(2.5 \%)$.

\section{CONCLUSION}

The results of this study suggest that females were found to be more commonly affected in all pathologies of gallbladder. We found chronic cholecystitis to be the most common histopathological diagnosis.

\section{KEY WORDS}

Cholecystectomy, Cholelithiasis, Tumour-Like Lesions, Chronic Cholecystitis, Gallbladder, Malignancy.

HOW TO CITE THIS ARTICLE: Mirza S, Kashif M, Ikram A. A retrospective histopathological study of 120 cases of cholecystectomy specimens in Barabanki District of Uttar Pradesh. J. Evolution Med. Dent. Sci. 2018;7(43):4659-4663, DOI: 10.14260/jemds/2018/1039

\section{BACKGROUND}

Gallbladder is an important organ of the body, where the storage and concentration of bile takes place. Normal capacity of adult gallbladder is $50 \mathrm{~mL}$. More than $95 \%$ of the biliary tract disease is attributed to cholelithiasis (Gall stones). The gall bladder pathology ranges from cholecystitis to highly lethal carcinoma. The number of cholecystectomies has increased more than $50 \%$ in the last 10 years.

The vast majority of surgeries were performed due to gall stones related pathology. The purpose of the present study is to classify different lesions of gallbladder (their respective frequency) in 120 cholecystectomies in the last 2 years in the Department of Pathology.

\section{Objective}

This retrospective descriptive study was undertaken with a purpose to determine the frequency and classify different histopathological lesions encountered in cholecystectomy specimens in Barabanki region of Eastern Uttar Pradesh.

'Financial or Other Competing Interest': None.

Submission 05-09-2018, Peer Review 02-10-2018,

Acceptance 09-10-2018, Published 22-10-2018.

Corresponding Author:

Mohammad Kashif,

Assistant Professor, Department of Paediatrics,

Mayo Institute of Medical Sciences,

Barabanki, Uttar Pradesh, India.

E-mail: kashifazmi@gmail.com

DOI: $10.14260 /$ jemds/2018/1039

\section{(c) $(1)$}

\section{MATERIALS AND METHODS}

This is a retrospective descriptive study which includes 120 gallbladder specimens collected over a period of 2 years in the Department of Pathology, Mayo Institute of Medical Sciences, from Barabanki region in Eastern Uttar Pradesh, India. The study was conducted to reveal the various pathologies of gallbladder which included cholecystitis, cholelithiasis, dysplasia, tumour-like lesions and malignancy.

The specimens were incised and left overnight for proper fixation. Later grossing was performed as per standard protocol.[1,2] The sections were taken from cystic duct, fundus, body and neck. If found, additional sections were taken from lymph node and from growth/ ulcer or thickening of the gallbladder wall. The tissues were processed as per the standard routine processing technique and later stained with $\mathrm{H}$ and $\mathrm{E}$ stain.

\section{RESULTS}

The prepared stained slides were analysed microscopically and accordingly classified into various categories like acute cholecystitis, chronic cholecystitis with and without cholelithiasis, cholesterosis, xanthogranulomatous cholecystitis, adenomatous hyperplasia, polyp, dysplasia and malignancy. Variables of patient's characteristics were taken into account which included age, sex and religion. A detailed correlation was made between patient's characteristics and different gallbladder pathologies. 


\begin{tabular}{|c|c|c|c|}
\hline Age & $\begin{array}{c}\text { Inflammatory } \\
\text { Acute/Chronic/ } \\
\text { Xanthogranulomatous) }\end{array}$ & $\begin{array}{c}\text { Tumour- } \\
\text { Like Lesion }\end{array}$ & Malignant \\
\hline $10-20$ & $3(2.5 \%)$ & $1(0.83 \%)$ & 0 \\
\hline $20-30$ & $23(19.0 \%)$ & $1(0.83 \%)$ & 0 \\
\hline $30-40$ & $28(23.33 \%)$ & $1(0.83 \%)$ & 0 \\
\hline $40-50$ & $23(19.0 \%)$ & $2(1.66 \%)$ & 0 \\
\hline $50-60$ & $16(13.0 \%)$ & $0(0 \%)$ & $1(0.83 \%)$ \\
\hline $60-70$ & $13(10.8 \%)$ & $1(0.83 \%)$ & 0 \\
\hline $\begin{array}{c}70-80 \\
\text { Yrs. }\end{array}$ & $4(3.0 \%)$ & $0(0 \%)$ & $2(1.7 \%)$ \\
\hline $\begin{array}{c}\text { Total } \\
(\mathbf{1 2 0})\end{array}$ & $\mathbf{1 1 0 ( 9 1 . 7 \% )}$ & $\mathbf{7 ( 6 . 0 \% )}$ & $\mathbf{3}(\mathbf{2 . 5 \% )}$ \\
\hline
\end{tabular}

Table 1. Correlation between Age and Histopathological Lesions (Total 120 Cases)

\begin{tabular}{|c|c|c|c|}
\hline Sex & $\begin{array}{c}\text { Inflammatory } \\
\text { (Acute/Chronic/ } \\
\text { Xanthogranulomatous) }\end{array}$ & $\begin{array}{c}\text { Tumour- } \\
\text { Like Lesion }\end{array}$ & Malignant \\
\hline Male & $23(19.2 \%)$ & $3(2.5 \%)$ & $0(0 \%)$ \\
\hline Female & $87(72.5 \%)$ & $4(3.0 \%)$ & $3(2.5 \%)$ \\
\hline $\begin{array}{c}\text { Total } \\
(120)\end{array}$ & $\mathbf{1 1 0}(\mathbf{9 1 . 7 \% )}$ & $\mathbf{7 ( 6 . 0 \% )}$ & $\mathbf{3}(\mathbf{2 . 5 \% )}$ \\
\hline \multicolumn{4}{|c|}{ Table 2. Correlation between Sex and Histopathological } \\
Lesions \\
\hline
\end{tabular}

\begin{tabular}{|c|c|c|c|}
\hline Religion & $\begin{array}{c}\text { Inflammatory } \\
\text { (Acute/Chronic/ } \\
\text { Xanthogranulomatous) }\end{array}$ & $\begin{array}{c}\text { Tumour- } \\
\text { Like } \\
\text { Lesion }\end{array}$ & Malignant \\
\hline Hindu & $83(69.2 \%)$ & $6(5.0 \%)$ & $2(1.7 \%)$ \\
\hline Muslim & $27(22.5 \%)$ & $1(0.83 \%)$ & $1(0.83 \%)$ \\
\hline $\begin{array}{c}\text { Total } \\
(120)\end{array}$ & $\mathbf{1 1 0}(91.7 \%)$ & $\mathbf{7 ( 6 . 0 \% )}$ & $\mathbf{3} \mathbf{2 . 5 \% )}$ \\
\hline \multicolumn{3}{|c|}{ Table 3. Correlation between Religion and } \\
Histopathological Lesions \\
\hline
\end{tabular}

\begin{tabular}{|c|c|c|c|}
\hline Age & Dysplasia & $\begin{array}{c}\text { Adenomatous } \\
\text { Hyperplasia }\end{array}$ & Polyp \\
\hline $10-20$ & 0 & $1(0.83 \%)$ & 0 \\
\hline $20-30$ & 0 & 0 & 0 \\
\hline $30-40$ & 0 & $2(1.7 \%)$ & 0 \\
\hline $40-50$ & $1(0.83 \%)$ & 0 & $1(0.83 \%)$ \\
\hline $50-60$ & $1(0.83 \%)$ & 0 & 0 \\
\hline $60-70$ & 0 & $1(0.83 \%)$ & 0 \\
\hline $70-80$ & 0 & 0 & 0 \\
\hline $\begin{array}{c}\text { Total } \\
\text { (07) }\end{array}$ & $2(1.7 \%)$ & 4 (3.3\%) & 1 (0.83\%) \\
\hline Table 4. Correlation between Age and Tumour-Like Lesion \\
\hline
\end{tabular}

\begin{tabular}{|c|c|c|c|}
\hline Sex & Dysplasia & $\begin{array}{c}\text { Adenomatous } \\
\text { Hyperplasia }\end{array}$ & Polyp \\
\hline Male & 0 & $2(1.7 \%)$ & $1(0.83 \%)$ \\
\hline Female & $2(1.7 \%)$ & $2(1.7 \%)$ & 0 \\
\hline $\begin{array}{c}\text { Total } \\
(07)\end{array}$ & $\mathbf{2 ( 1 . 7 \% )}$ & $\mathbf{4 ( 3 . 3 3 \% )}$ & $\mathbf{1 ( 0 . 8 3 \% )}$ \\
\hline
\end{tabular}

Table 5. Correlation between Sex and Tumour-Like Lesions

\begin{tabular}{|c|c|c|c|}
\hline Religion & Dysplasia & $\begin{array}{c}\text { Adenomatous } \\
\text { Hyperplasia }\end{array}$ & Polyp \\
\hline Hindu & $1(0.83 \%)$ & $3(2.5 \%)$ & $1(0.83 \%)$ \\
\hline Muslim & $1(0.83 \%)$ & $1(0.83 \%)$ & - \\
\hline $\begin{array}{c}\text { Total } \\
\text { (07) }\end{array}$ & $2(1.7 \%)$ & $4(3.33 \%)$ & $1(0.83 \%)$ \\
\hline Table 6. Correlation between Religion and Tumour-Like \\
Lesions \\
\hline
\end{tabular}

\begin{tabular}{|c|c|c|c|c|c|}
\hline$\stackrel{\Xi}{\alpha}$ & نئ & بّ & 䓠 & 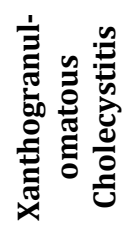 & 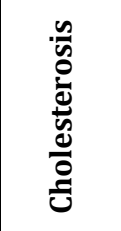 \\
\hline $10-20$ yrs. & \begin{tabular}{|c}
02 \\
$(1.67 \%)$ \\
\end{tabular} & $\begin{array}{c}01 \\
(0.83 \%) \\
\end{array}$ & \begin{tabular}{|c|}
01 \\
$(0.83 \%)$ \\
\end{tabular} & 00 & \begin{tabular}{|c|}
01 \\
$(0.83 \%)$ \\
\end{tabular} \\
\hline 20-30 yrs. & $\begin{array}{c}10 \\
(8.3 \%) \\
\end{array}$ & $\begin{array}{c}06 \\
(05 \%) \\
\end{array}$ & \begin{tabular}{|c|}
01 \\
$(0.83 \%)$ \\
\end{tabular} & 00 & $\begin{array}{c}03 \\
(2.5 \%) \\
\end{array}$ \\
\hline $30-40$ yrs. & $\begin{array}{c}12 \\
(10.0 \%) \\
\end{array}$ & $\begin{array}{c}05 \\
(4.2 \%) \\
\end{array}$ & 00 & $\begin{array}{c}01 \\
(0.83 \%) \\
\end{array}$ & $\begin{array}{c}02 \\
(1.7 \%)\end{array}$ \\
\hline $40-50$ yrs. & $\begin{array}{c}19 \\
(15.8 \%) \\
\end{array}$ & $\begin{array}{c}10 \\
(8.3 \%)\end{array}$ & 00 & 00 & $\begin{array}{c}03 \\
(2.5 \%)\end{array}$ \\
\hline 50-60 yrs. & \begin{tabular}{|c|}
06 \\
$(5.0 \%)$ \\
\end{tabular} & $\begin{array}{c}08 \\
(6.7 \%) \\
\end{array}$ & $\begin{array}{c}01 \\
(0.83 \%) \\
\end{array}$ & 00 & $\begin{array}{c}02 \\
(1.7 \%) \\
\end{array}$ \\
\hline $60-70$ yrs. & $\begin{array}{c}03 \\
(2.5 \%) \\
\end{array}$ & $\begin{array}{c}03 \\
(2.5 \%) \\
\end{array}$ & $\begin{array}{c}02 \\
(1.7 \%) \\
\end{array}$ & 00 & $\begin{array}{c}05 \\
(4.2 \%) \\
\end{array}$ \\
\hline $70-80$ yrs. & $\begin{array}{c}01 \\
(0.83 \%) \\
\end{array}$ & $\begin{array}{c}02 \\
(1.7 \%) \\
\end{array}$ & 00 & 00 & 00 \\
\hline Total 110 & $\begin{array}{c}53 \\
(44.2 \%)\end{array}$ & $\begin{array}{c}35 \\
(29.2 \%)\end{array}$ & $\begin{array}{c}05 \\
(4.2 \%)\end{array}$ & $\begin{array}{c}01 \\
(0.83 \%)\end{array}$ & $\begin{array}{c}16 \\
(13.3 \%)\end{array}$ \\
\hline
\end{tabular}

CC-CL\#- Chronic cholecystitis without cholelithiasis.

$\mathrm{CC}+\mathrm{CL}^{*}$ - Chronic cholecystitis with cholelithiasis.

\begin{tabular}{|c|c|c|c|c|c|}
\hline 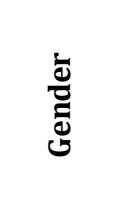 & بئِ & 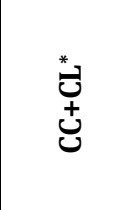 & 总 & 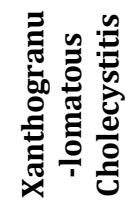 & $\begin{array}{l}\frac{n}{5} \\
\frac{0}{d} \\
\frac{\tilde{d}}{0} \\
\frac{0}{0}\end{array}$ \\
\hline Male & $\begin{array}{c}13 \\
(10.8 \%) \\
\end{array}$ & $\begin{array}{c}05 \\
(4.2 \%) \\
\end{array}$ & $\begin{array}{c}02 \\
(1.7 \%) \\
\end{array}$ & 00 & $\begin{array}{c}02 \\
(1.7 \%) \\
\end{array}$ \\
\hline Female & $\begin{array}{c}40 \\
(33.3 \%)\end{array}$ & $\begin{array}{c}30 \\
(25 \%)\end{array}$ & $\begin{array}{c}03 \\
(2.5 \%)\end{array}$ & $\begin{array}{c}01 \\
(0.83 \%)\end{array}$ & $\begin{array}{c}14 \\
(11.7 \%)\end{array}$ \\
\hline $\begin{array}{c}\text { Total } \\
110\end{array}$ & $\begin{array}{c}53 \\
(44.2 \%)\end{array}$ & $\begin{array}{c}35 \\
(29.2 \%)\end{array}$ & $\begin{array}{c}05 \\
(4.2 \%)\end{array}$ & $\begin{array}{c}01 \\
(0.83 \%)\end{array}$ & $\begin{array}{c}16 \\
(13.4 \%)\end{array}$ \\
\hline
\end{tabular}

CC-CL\#- Chronic cholecystitis without cholelithiasis.

$\mathrm{CC}+\mathrm{CL}^{*}$ - Chronic cholecystitis with cholelithiasis.

\begin{tabular}{|c|c|c|c|c|c|}
\hline 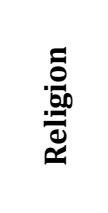 & لئ & 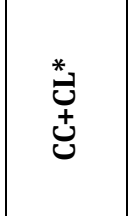 & 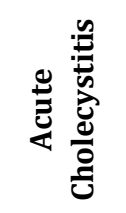 & 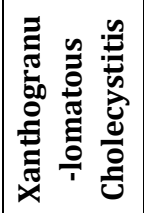 & $\begin{array}{l}\frac{n}{5} \\
\frac{0}{0} \\
\frac{\tilde{d}}{0} \\
\frac{0}{0}\end{array}$ \\
\hline Hindu & $\begin{array}{c}35 \\
(29.2 \%)\end{array}$ & $\begin{array}{c}24 \\
(20 \%)\end{array}$ & $\begin{array}{c}04 \\
(3.3 \%)\end{array}$ & 00 & $\begin{array}{c}11 \\
(9.2 \%)\end{array}$ \\
\hline Muslim & $\begin{array}{c}18 \\
(15.0 \%)\end{array}$ & $\begin{array}{c}11 \\
(9.2 \%)\end{array}$ & $\begin{array}{c}01 \\
(0.83 \%)\end{array}$ & $\begin{array}{c}01 \\
(0.83 \%)\end{array}$ & $\begin{array}{c}05 \\
(4.2 \%)\end{array}$ \\
\hline $\begin{array}{c}\text { Total } \\
110\end{array}$ & $\begin{array}{c}53 \\
(44.2 \%)\end{array}$ & $\begin{array}{c}35 \\
(29.2 \%)\end{array}$ & $\begin{array}{c}05 \\
(4.2 \%)\end{array}$ & $\begin{array}{c}01 \\
(0.83 \%)\end{array}$ & $\begin{array}{c}16 \\
(13.3 \%\end{array}$ \\
\hline \multicolumn{6}{|c|}{$\begin{array}{c}\text { Table 9. Showing Inflammatory Pathologies in different } \\
\text { Religion Groups }\end{array}$} \\
\hline
\end{tabular}

CC-CL\#- Chronic cholecystitis without cholelithiasis.

$\mathrm{CC}+\mathrm{CL}^{*}$ - Chronic cholecystitis with cholelithiasis. 


\begin{tabular}{|c|c|}
\hline Disease & Number of Cases \\
\hline Chronic cholecystitis & $35(29.2 \%)$ \\
\hline Acute cholecystitis & 00 \\
\hline Xanthogranulomatous cholecystitis & 00 \\
\hline Cholesterosis & $3(2.5 \%)$ \\
\hline Polyp & 00 \\
\hline Adenoma & $3(2.5 \%)$ \\
\hline Dysplasia & 00 \\
\hline Adenocarcinoma & $2(1.7 \%)$ \\
\hline \multicolumn{2}{|c|}{ Total (120) } \\
\hline $\begin{array}{c}\text { Table 10. Showing Gall Stones association with different } \\
\text { Pathologies of Gallbladder }\end{array}$
\end{tabular}

Classification of different Gallbladder pathologies with respect to patient characteristics-

Age and Sex Distribution of Patients

Out of 120 cases, there were 26 males and 91 females with M:F of 1: 3.5. The age ranged from 10 years to 80 years with average age of 45 years. Out of 120 gallbladder specimens, inflammatory pathology was the most common diagnosis (91.7\%), affecting more females (72.5\%) than males (19.2\%) and the age group involved was $30-40$ years.

\section{Religion Wise Distribution}

Out of 120 cases, $83(69.2 \%)$ number of cases of Hindu and $27(22.5 \%)$ number of cases of Muslims with ratio of 3.1: 1. The most common diagnosis among both the religions turn out to be inflammatory pathology.

\section{Different Categories of Gall Bladder Pathologies}

\section{Cholelithiasis}

In the present study gallstones were seen in 43 number of cases $(35.8 \%)$, which included $8(6.7 \%)$ males and 35 (29.2\%) females. Gallstones were most frequently seen in chronic cholecystitis 35 (29.2\%); however, they are also seen in other pathologies such as cholesterosis 3 (2.5\%), adenomatous hyperplasia $3(2.5 \%)$ and adenocarcinoma $2(1.7 \%)$.

2. Acute Cholecystitis- Correlating the diagnosis with age, among total 5 patients, 2 cases $(1.7 \%)$ were in the range of 60-70 yrs., 4 (3.3\%) patients were Hindus and 1 (0.83\%) patient was Muslim. Females were more affected than males.

3. Chronic Cholecystitis- With/ without cholelithiasis were reported, maximum in the age group of $40-50$ yrs. There were 40 females and 13 males who presented with chronic cholecystitis without cholelithiasis and 30 females and 5 males were presented with chronic cholecystitis with cholelithiasis. When correlation was made with religion, 35 Hindu patients presented with chronic cholecystitis without cholelithiasis and 24 patients with chronic cholecystitis with cholelithiasis. 18 Muslim patients had chronic cholecystitis without cholelithiasis and 11 had chronic cholecystitis with cholelithiasis.

\section{Cholesterosis}

16 patients reported of cholesterosis, among which maximum number of cases (5) were in the range of 60 - 70 yrs. Females (14) were affected more than males (2). There were 11 Hindu patients and 5 Muslim patients.

\section{Xanthogranulomatous Cholecystitis}

There was only 1 case of xanthogranulomatous cholecystitis with age group of 30 - 40 yrs., who was a Hindu female.

\section{Dysplasia}

This is a precursor lesion of gallbladder malignancies, characterised by enlarged non-polarised hyperchromatic nuclei. In the present study, there were 2 cases. All of them were Hindu females in the group of 40 - 60 yrs.

\section{Adenomatous Hyperplasia}

Adenomatous hyperplasia of the gallbladder is considered a benign pseudotumour of the gallbladder and has no known malignant potential. Adenomatous hyperplasia were demonstrated in 4 cases (3.33\%), among which maximum presented in $30-40$ yrs. Male: female ratio is $1: 1$. There were 3 Hindu patients and 1 Muslim patient.

\section{Polyp}

A single case of polyp was identified who was a 46 years old Hindu male.

\section{Adenocarcinoma}

In 120 cases, $3(2.5 \%)$ cases were reported as adenocarcinoma. All the patients were female, within the age group of 50 - 70 years. Among 3 patients, 2 (1.7\%) patients were Hindus and $1(0.83 \%)$ was Muslim.

\section{DISCUSSION}

Total 120 patients with gallbladder pathologies operated for cholecystectomy were studied during January 2016 December 2017 period. The age of patients with gallbladder disease ranged from 10 years to 80 years and were most commonly found in the $4^{\text {th }}$ decade. There were 23 males and 87 females with Male/ Female Ratio in our study of 1: 3.5, which showed predominance of females over males. The results are comparable to Thamil Selvi et al,[3] Almuslamani et $\mathrm{al}^{[4]}$ and Baidya et $\mathrm{al}^{[5]}$ who concluded that male: female ratio was 1:1.6, 1:2.7 and 1:1.8 with predominance of female patients.

Thamil Selvi et al[4] and Vahini et al[6] found the maximum incidence of gallstones in the $6^{\text {th }}$ decade and $5^{\text {th }}$ decade respectively. Our study showed maximum incidence in $4^{\text {th }}$ decade similar to Rakesh $\mathrm{BH}$ et al[7] found $4^{\text {th }}$ decade is the most commonly affected group.

Our study were similar to that of Khanna et al[8] Thamil Selvi,[3] Almuslamani et al,[4] Baidya et al[5] and Costa et al[9] are all of the opinion that chronic cholecystitis is the most frequent histopathological condition associated with gallstones. The normal prevalence of gallstones ranges from $11-36 \% .{ }^{[10]}$ The estimated prevalence of gallstones disease in India has been reported as $2-29 \%$ by Mohan $\mathrm{H}$ et al[11] study and in our study gallstone disease prevalence was $35.8 \%$.

In our study, the mean age of patients with acute cholecystitis was 65 years. This observation was also concurrent with previous study done by Glenn et al,[12] who reported that it was more frequent in patients older than 65 years of age. The frequency of acute cholecystitis was found to be $4.2 \%$ in our study, as Tadashi Terada[13] study showed $1.5 \%$ of cases of acute cholecystitis. Acute cholecystitis was 
diagnosed more in females as compared to males in our study, which were similar to study done by Kumar H et al.[14] However, Glenn F study showed male predominance.[12]

The incidence of cholesterosis was reported to be $2.7 \%$ in Tyagi SP et al study.[15] In our study incidence of cholesterosis was found to be $13.3 \%$ as compared to Tadashi Terada study, in which there was $11 \%$ incidence of cholesterosis.

Our study was similar to that of Rao et al[16] that Cholesterosis was more common in women $(11.7 \%)$ than in men $(1.7 \%)$.

Xanthogranulomatous cholecystitis is an uncommon inflammatory and destructive gallbladder process. In our study, single case $(0.83 \%)$ was diagnosed as xanthogranulomatous cholecystitis and not associated with gallstone. However, Kumar $\mathrm{H}$ et al reported two cases of it and both are associated with stones.

In our study, 4 cases of adenomatous hyperplasia (3.33\%) were reported with maximum patients presented in 30-40 years with equal incidence in male and female patients. However, study done by Mathur et al[17] and Stancu et al[18] observed that incidence of adenomatous hyperplasia were $8 \% / 7.8 \%$ respectively.

The prevalence of GB polyp was reported as $0.83 \%$. In our study, however, prevalence rate of GB polyp were found to be 4.3 - 6.9\% in Ake Andren study.[19]

We found that mean age for dysplasia to be 50 years, similar to Mukhopadhyay et al[20] study in which mean age was 52.6 years. Two cases of dysplasia were found in females in our study. Kumar $\mathrm{H}$ et al found seven cases of dysplasia with female predominance.

Gall bladder carcinoma is the most common cancer of biliary tree and the $5^{\text {th }}$ most common gastrointestinal malignancy. (Bartlett, 2000; Lam et al., 2005; Shih et al., 2997). It is characterised by rapid progression and very high mortality rate. The incidence of gallbladder cancer varies by geographic region and racial ethnic group. The highest incidences are reported in Indians, Pakistanis, Chileans, Bolivians, Central Europeans, Israelis, Native Americans and Americans of Mexican origin (Lazcano-Ponce et al, 2001; Randi et al, 2006).

In our study, average age of gallbladder cancer was found to be 65 years ranging from 50 - 80 years. Our study was similar to that of Perpetuo et al.[21] However, Shukla et al[22] reported mean age of the patient to be 50 years (range 40-60 years).

Carcinoma of the gallbladder is predominantly a disease of elderly females, also common finding in our present study, similar to that of Shukla et al ${ }^{[22]}$ and Henson et al[23] studies.

In our study gallbladder carcinoma is most common among the Hindu females, whereas a case control study done by Varsha et al[24] showed both Hindus and Muslims possessing equal risk of gall bladder cancer.

\section{CONCLUSION}

The results of this study suggest that females were found to be more commonly affected in all pathologies of gallbladder. We found chronic cholecystitis to be the most common histopathological diagnosis.

\section{REFERENCES}

[1] Lester SC. Gastrointestinal, hepatobiliary and pancreatic specimens. In: Manual of surgical pathology. Philadelphia: Churchill Livingstone 2001: p. 174-208.

[2] Sharriff S, Makhija P. Liver and gallbladder. In: Sharriff $S$, edr. Laboratory techniques in surgical pathology. Bangalore: Prism Books Pvt Ltd. 1999: p. 70-4.

[3] Selvi TR, Sinha P, Subramaniam PM, et al. A clinicopathological study of cholecystitis with special reference to analysis of cholelithiasis. International Journal of Basic Medical Science 2011;2(2):68-72.

[4] Almuslamani AJ, Alsoude $\mathrm{M}$, Alomari $\mathrm{M}$, et al. Histopathological examination on suspicious gallbladder specimens at Royal Medical services hospitals. Rawal Med Journal 2011;36(2):93-6.

[5] Baidya R, Sigdel B, Baidya NL. Histopathological changes in gallbladder mucosa associated with cholelithasis. J of Path of Nepal 2012;2:224-5.

[6] Vahini G, Premalatha P, Mathi A, et al. A clinicopathological study of gallbladder lesions. IOSRJDMS 2015;14(2), Ver III:15-20.

[7] Rakesh BH, Rajendra GC. A prospective clinicopathological study of 50 cases of chronic calculous cholecystitis in the local population. JEMDS 2013;2(35):6706-16.

[8] Khanna R, Chansuria R, Kumar M, et al. Histological changes in gallbladder due to stone disease. Indian Journal of Surg 2006;68(4):201-4.

[9] Meirelles-Costa ALA, Bersciani CJC, Perez RO, et al. Are histological alterations observed in Gallbladder precancerous lesions? Clinics (Sao Paulo) 2010;65(2):143-50.

[10] Sharma A, Agarwal M, Chanchlani R, et al. A study of epidemiology of gallbladder carcinoma and cholelithiasis at a tertiary institute in Central India. JEMDS 2014;3(15):4023-8.

[11] Mohan H, Punia RPS, Dhawan SB, et al. Morphological spectrum of gallstone disease in 1100 cholecystectomies in North India. Indian J Surg 2005;67(3):140-2.

[12] Glenn F. Acute acalculous cholecystitis. Ann Surg 1979;189(4):458-65.

[13] Terada T. Histopathologic features and frequency of gallbladder lesions in consecutive 540 cholecystectomies. Int J Clin Exp Pathol 2013;6(1):91-6.

[14] Kumar H, Kini H, Tiwari A. Histological evaluation of 400 cholecystectomy specimens. Journal of pathology of Nepal 2015;5(10):834-84.

[15] Tyagi SP, Tyagi N, Maheswari V, et al. Morphological changes in diseased gallbladder: a study of 415 cholecystectomies at Aligarh. Journal Indian Med Assoc 1992;90(7):178-81.

[16] Rao I, Araya JC, Villaseca M, et al. Preneoplastic lesions and gallbladder cancer, an estimate of the period required for progression. Gasteroenterology 1996;111(1):232-6.

[17] Mathur SK, Duhan A, Singh S, et al. Correlation of gallstone characteristics with mucosal changes in gallbladder. Tropical Gastroenterol 2012;33(1):39-44. 
[18] Stancu M, Caruntu ID, Giusca S, et al. Hyperplasia, metaplasia, dysplasia and neoplasia lesions in chronic cholecystitis- a morphologic study. Rommonian J Morphol Embryol 2007;48(4):335-42.

[19] Andren-Sandberg A. Diagnosis and management of gallbladder polyps. N Am J Med Sci 2012;4(5):203-11.

[20] Mukhopadhyay S, Landas SK. Putative precursors of gallbladder dysplasia: a review of 400 routinely resected specimens. Archives Pathol Lab Medicine 2005;129(3):386-90.

[21] Perpetuo MD, Valdivieso M, Heilbrun LK, et al. Natural history study of gallbladder cancer: a review of 36 years experience at M.D. Anderson Hospital and Tumour Institute. Cancer 1978;42(1):330-5.
[22] Shukla HS, Awasthi K, Naithani YP, et al. A clinico pathological study of carcinoma of gallbladder. Ind $\mathrm{J}$ Cancer 1981;18(3):198-201.

[23] Henson DE, Albores-Saavendra J, Corle D. Carcinoma of the gallbladder, histologic types, stage of disease, grade and survival rates. Cancer 1992;70(6):1493-7.

[24] Singh V. Factors associated with gallbladder cancer in Bihar - a case control study. MAE-FETP Scholar 20042006. 